\title{
TINGKAT KECUKUPAN VITAMIN A, SENG DAN ZAT BESI SERTA FREKUENSI INFEKSI PADA BALITA STUNTING DAN NON STUNTING
}

\section{Adequacy Levels of Vitamin A, Zinc, Iron, and Frequency of Infections among Stunting and Non Stunting} Children Under Five

\author{
Nabilla Siti Hawa Fatimah ${ }^{*}$, R. Bambang Wirjatmadi \\ ${ }^{1}$ Program Studi S1 Kesehatan Masyarakat, Universitas Airlangga, Surabaya \\ ${ }^{2}$ Departemen Gizi Kesehatan, Fakultas Kesehatan Masyarakat, Universitas Airlangga, Surabaya \\ E-mail: nabillasihaft@yahoo.com
}

\begin{abstract}
ABSTRAK
Stunting merupakan gangguan pada pertumbuhan linier. Kekurangan zat gizi mikro seperti vitamin A, seng dan zat besi dapat mengganggu sekresi hormon pertumbuhan pada tulang panjang. Infeksi akan meningkatkan Tumor Necrosis Factor Alpha (TNF- $\alpha$ ) dan Interleukin 1 (IL-1) sehingga menekan sekresi hormon pertumbuhan. Penelitian ini bertujuan untuk mengetahui perbedaan tingkat kecukupan vitamin A, seng, zat besi serta frekuensi infeksi pada balita stunting dan non stunting di wilayah kerja Puskesmas Bulak Banteng Surabaya. Penelitian dilakukan pada Januari-Mei 2017 menggunakan desain cross sectional. Sampel penelitian seluruhnya 38 balita dengan 19 balita stunting dan 19 balita non stunting yang dipilih dengan random sampling. Analisis yang digunakan yakni uji Mann Whitney. Terdapat perbedaan yang signifikan antara kelompok stunting dan non stunting pada variabel tingkat kecukupan vitamin A ( $\mathrm{p}=0,002)$, seng $(p=0,003)$ dan zat besi $(p=0,030)$. Tidak ada perbedaan riwayat ISPA dan Diare yang signifikan antar kelompok. Asupan vitamin A, seng, dan zat besi pada usia pertumbuhan perlu ditingkatkan untuk mencegah terjadinya stunting.
\end{abstract}

Kata kunci: infeksi, seng, stunting, vitamin A, zat besi

\section{ABSTRACT}

Stunting is a disturbance in linear growth. Deficiency of micronutrients such as vitamin A, zinc, and iron may disturb secretion of growth hormone. Infection may improve Tumor Necrosis Factor Alpha (TNF- $\alpha$ ) and Interleukin 1 (IL-1) that pressing secretion of growth hormone. The purpose of this study is to determine difference adequacy levels of vitamin A, zinc, iron and frequency infection in stunting and non stunting children under five at Puskesmas Bulak Banteng Surabaya. The study was conducted from January to may 2017 with cross sectional design. Thirty-eight children (19 stunting and 19 non stunting) were selected from random sampling. Mann Whitney test was conducted to analyze the differences between variabel in stunting and non stunting. Variable that were significantly different between two groups were vitamin $A(p=0.002)$, zinc $(p=0.003)$ and iron adequacy level $(p=0.030)$. There were no significant differences in frequency of diarrhea and acute respiratory infection among both groups. Vitamin A, zinc, and iron intake should be fullfilled in order to prevent stunting.

Keywords: infection, zinc, stunting, vitamin A, iron

\section{PENDAHULUAN}

Stunting merupakan gangguan yang terjadi pada pertumbuhan linier sehingga menyebabkan tinggi badan tidak sesuai dengan umur. Stunting sejak usia dini dapat memiliki dampak pada nilai akademik yang rendah di sekolah, tinggi badan yang pendek dan bersifat menetap di usia dewasa, dan kurangnya kemampuan motorik di usia sekolah sehingga memengaruhi produktivitas serta meningkatnya risiko penyakit degeneratif di usia dewasa (Hoddinott et al., 2013).

Prevalensi balita stunting di wilayah kerja Puskesmas Bulak Banteng Surabaya dalam tiga tahun terakhir terus mengalami peningkatan. Pada tahun 2013, terdapat 26,13\% anak stunting. Jumlah ini meningkat menjadi $29,23 \%$ di tahun 2014 dan 30,25\% pada tahun 2015 (DKK, 2016). 
Stunting terjadi akibat dampak akumulasi dari tidak tercukupinya zat gizi, kondisi kesehatan yang buruk dan pengasuhan yang kurang memadai (Aridiyah et al., 2015). Pemenuhan zat gizi pada masa balita memiliki pengaruh pada tinggi badan yang akan terlihat pada waktu yang relatif lama sehingga indeks tinggi badan per umur $(\mathrm{TB} / \mathrm{U})$ dapat menggambarkan status gizi masa lalu dan perlu adanya evaluasi untuk upaya perbaikan dan pencegahan.

Asupan zat gizi yang tidak adekuat merupakan penyebab langsung terjadinya stunting. Defisiensi zat gizi mikro juga berpengaruh terhadap pertumbuhan linier (Mikhail, 2013). Defisiensi zat gizi vitamin A, seng dan zat besi dapat memengaruhi kejadian stunting pada balita (Suiraoka, 2011; Damayanti et al., 2016).

Infeksi dalam tubuh memicu peradangan sehingga meningkatkan sitokin TNF- $\alpha$ dan IL-1 . Sitokin yang meningkat akan menurunkan GH (Growth Hormone) sehingga menurunnya stimulasi produksi IGF-1 yang penting bagi pertumbuhan lempeng epifisis tulang panjang pada anak balita (Adriani dan Wirjatmadi, 2012).

Penelitian ini bertujuan untuk mengetahui perbedaan tingkat kecukupan vitamin A, seng dan zat besi serta frekuensi diare dan ISPA pada balita stunting dan non stunting usia 24-59 bulan di wilayah kerja Puskesmas Bulak Banteng Surabaya.

\section{METODE}

Jenis penelitian ini merupakan penelitian observasional dengan desain cross sectional dan rancang bangun menggunakan studi komparasi. Penelitian dilakukan pada bulan Januari hingga bulan Mei 2017 di wilayah kerja Puskesmas Bulak Banteng Surabaya. Penelitian telah mendapat persetujuan dari komisi etik penelitian kesehatan Fakultas Kesehatan Masyarakat Universitas Airlangga No. 655-KEPK.

Populasi balita yang tercatat di wilayah kerja Puskesmas Bulak Banteng sebanyak 3025 balita. Sub populasi diambil menggunakan kriteria balita yang berusia 24-59 bulan, tidak sakit dan tidak mengalami cacat bawaan. Sampel penelitian adalah keluarga yang memiliki balita yang telah dilakukan sesuai kriteria inklusi. Sampel penelitian dihitung menggunakan rumus sebagai berikut (Kuntoro, 2008):

$$
\mathrm{n}_{1}=\mathrm{n}_{2}=\frac{\left[\mathrm{Z}_{1 / 2 \alpha} \sqrt{2} \mathrm{PQ}-\mathrm{Z}_{1-\beta} \sqrt{ } \mathrm{P}_{1} \mathrm{Q}_{1}+\mathrm{P}_{2} \mathrm{Q}_{2}\right]^{2}}{\left(\mathrm{P}_{2}-\mathrm{P}_{1}\right)^{2}}
$$

P1 sebesar 0,73 didapatkan dari proporsi balita stunting yang mengalami sakit infeksi tiga bulan terakhir (Suiraoka, 2011). P2 merupakan proporsi balita non stunting. Nilai $\mathrm{P}$ merupakan rata-rata proporsi kedua populasi. nilai Q didapat dari 1-P. Sampel penelitian diperoleh 19 balita dan karena rancang bangun penelitian ini adalah komparasi maka total jumlah sampel sebanyak 38 balita.

Variabel dalam penelitian ini meliputi variabel bebas yakni karakteristik balita (usia dan jenis kelamin), pola konsumsi (jenis makanan yang dikonsumsi, frekuensi konsumsi, jumlah konsumsi vitamin $A$, seng dan zat besi), tingkat kecukupan (vitamin A, seng dan zat besi) serta frekuensi infeksi (diare dan ISPA). Variabel terikat dalam penelitian ini adalah status gizi balita berdasarkan indeks tinggi badan per umur (TB/U).

Data karakteristik balita, jenis konsumsi serta frekuensi diare dan ISPA didapatkan dari hasil wawancara dengan ibu balita menggunakan kuesioner. Frekuensi konsumsi didapatkan dari food frequency questionnaire ( $F F Q$ ). Jumlah konsumsi vitamin $\mathrm{A}$, seng dan zat besi didapatkan dari form food recall $1 \times 24$ hours dan diolah menggunakan aplikasi nutrisurvey. Tingkat kecukupan vitamin A, seng dan zat besi didapatkan dari rata-rata jumlah konsumsi yang telah dibandingkan dengan Angka Kecukupan Gizi.

Data mengenai tinggi badan didapatkan dari pengukuran tinggi badan menggunakan alat microtoise. Hasil pengukuran tinggi badan balita berdasarkan standar baku WHO-2005 makan balita dengan hasil z-score $<-2$ SD termasuk stunting dan $\geq-2$ SD termasuk non stunting.

Usia balita secara fisiologis dan kebutuhan zat gizi dikategorikan menjadi dua yakni batita dan prasekolah (Adriani dan Wirjatmadi, 2012). Batita 
yakni anak usia 24-36 bulan dan pra sekolah anak usia $37-59$ bulan.

Tingkat kecukupan vitamin A, seng dan zat besi dikatakan baik jika mencapai $\geq 100 \%$ AKG, sedang jika 80-99,9\% AKG, kurang jika 70-79,9\% AKG dan defisit jika $<70 \%$ AKG (Chaerunnimah, 2011). Frekuensi diare dan ISPA dalam tiga bulan terakhir dikategorikan menjadi empat yakni sering jika frekuensi sakit $\geq 6$ kali, kadang jika 3-5 kali, jarang jika 1-2 kali dan tidak pernah jika tidak pernah sakit (Suiraoka, 2011). Data mengenai tingkat kecukupan dan frekuensi infeksi dianalisis menggunakan aplikasi SPSS 21. Perbedaan tingkat kecukupan vitamin A, seng dan zat besi serta frekuensi infeksi dianalisis menggunakan uji Mann Whitney dengan $\alpha=5 \%$.

\section{HASIL DAN PEMBAHASAN}

\section{Karakteristik Balita}

Status gizi merupakan hasil akhir dari keseimbangan zat gizi yang masuk dalam tubuh dengan kebutuhan. Kebutuhan zat gizi ditentukan banyak faktor diantaranya umur, jenis kelamin, dan aktivitas fisik maupun kondisi individu (Adriani dan Wirjatmadi, 2012). Distribusi karakteristik balita stunting dan non stunting dapat dilihat pada Tabel 1.

Usia balita stunting dalam penelitian ini jika dilihat pada Tabel 1 sebanyak 53,3\% berusia batita yakni usia 24-36 bulan. Hasil penelitian ini sejalan dengan penelitian Suiraoka (2011) di Karangasem Bali bahwa sebaran umur balita stunting paling banyak pada usia 24-25 bulan. Pemenuhan kebutuhan zat gizi pada usia batita sangat penting karena pada usia tersebut pertumbuhan mencapai kecepatan tertinggi (Adriani dan Wirjatmadi, 2012). Usia balita merupakan periode emas perkembangan otak (Adriani dan Wirjatmadi, 2012). Penelitian Picauly dan Toy (2013). Menunjukkan bahwa stunting memiliki dampak signifikan terhadap prestasi anak usia sekolah dasar di Kupang dan Sumba Timur.

Tabel 1 menunjukkan bahwa $61,1 \%$ balita stunting berjenis kelamin laki-laki. Penelitian pada balita di Bangladesh dan di Indonesia menunjukkan bahwa balita laki-laki banyak yang mengalami stunting (Khan et al., 2011; Roscha et al., 2013).

\section{Pola Konsumsi}

Pola konsumsi merupakan kebiasaan makan yang terbentuk dari perilaku makan yang berulang dalam jangka waktu lama. Pola konsumsi dapat dilihat dari jenis makanan yang dikonsumsi, frekuensi makan dan jumlah makanan yang dikonsumsi.

Jenis makanan sesuai pedoman gizi seimbang tahun 2014 terdiri dari makanan pokok, sayur, lauk pauk dan buah. Tabel 1 menunjukkan bahwa 1 dari 4 balita yang mengonsumsi makanan sesuai pedoman gizi seimbang sedangkan sisanya masih belum mengonsumsi makanan sesuai pedoman gizi seimbang.

Hasil dari wawancara dengan ibu balita menggunakan FFQ menunjukkan bahwa pangan lauk hewani lebih sering dikonsumsi oleh balita non stunting. Jenisnya lauk hewani yang dikonsumsi kedua kelompok sama yakni telur, daging ayam,

Tabel 1. Karakteristik Balita Stunting dan Pola Konsumsi Balita

\begin{tabular}{|c|c|c|c|c|}
\hline \multirow[t]{2}{*}{ Variabel } & \multicolumn{2}{|c|}{$\begin{array}{c}\begin{array}{c}\text { Stunting } \\
\mathrm{n}=19\end{array} \\
\end{array}$} & \multicolumn{2}{|c|}{$\begin{array}{c}\begin{array}{c}\text { Non stunting } \\
\mathrm{n}=19\end{array} \\
\text {. }\end{array}$} \\
\hline & $\mathbf{n}$ & $\%$ & $\mathbf{n}$ & $\%$ \\
\hline \multicolumn{5}{|l|}{ Usia Balita } \\
\hline Batita & 8 & 53,3 & 7 & 46,7 \\
\hline Prasekolah & 11 & 47,8 & 12 & 52,2 \\
\hline \multicolumn{5}{|l|}{ Jenis Kelamin } \\
\hline Laki-laki & 11 & 61,1 & 7 & 38,9 \\
\hline Perempuan & 8 & 40,0 & 12 & 60,0 \\
\hline \multicolumn{5}{|l|}{ Jenis Makanan } \\
\hline Makanan Pokok dan Lauk Pauk & 5 & 50,0 & 5 & 50,0 \\
\hline Makanan Pokok, Sayur dan Lauk Pauk & 9 & 56,3 & 7 & 43,7 \\
\hline Makanan Pokok, Sayur, Lauk Pauk dan Buah & 5 & 41,7 & 7 & 58,3 \\
\hline
\end{tabular}


Tabel 2. Rata-rata Asupan Vitamin A, Seng dan Zat Besi oleh Balita Stunting dan non Stunting

\begin{tabular}{lccc}
\hline \multicolumn{1}{c}{ Asupan } & Stunting & Non Stunting & p-value \\
\hline Vitamin A (mcg) & $298,7 \pm 167,2 \mathrm{mcg}$ & $599,5 \pm 415,3 \mathrm{mcg}$ & 0,006 \\
Seng (mg) & $3,3 \pm 1,1 \mathrm{mg}$ & $5,3 \pm 2,6 \mathrm{mg}$ & 0,005 \\
Zat Besi (mg) & $4,3 \pm 1,1 \mathrm{mg}$ & $8,8 \pm 7,6 \mathrm{mg}$ & 0,024 \\
\hline
\end{tabular}

tongkol, pindang dan mujair. Jenis susu yang banyak dikonsumsi oleh kedua kelompok adalah susu kental manis. Susu kental manis menurut daftar komposisi bahan makanan, $64 \%$ dari total energi berasal dari gula (Hardiansyah, 2008). Susu sapi mengandung zat bioaktif, vitamin dan mineral yang dibutuhkan tubuh (Wardyaningrum, 2011). Lauk nabati tahu dan tempe lebih sering dikonsumsi oleh balita non stunting. Frekuensi dan jenis konsumsi sayuran kedua kelompok kesamaan. Jenis sayur yang dikonsumsi adalah wortel, kubis, buncis dan bayam, namun balita stunting lebih banyak mengonsumsi kuah sayur saja.

Frekuensi dan jenis konsumsi buah pada kedua kelompok memiliki kesamaan. Jenis buah yang dikonsumsi yakni pisang, semangka dan jeruk. Tabel 2 menunjukkan rata-rata asupan vitamin A, seng dan zat besi balita stunting lebih rendah dibandingkan dengan balita non stunting (Tabel 2). Uji Mann Whitney menunjukkan ada perbedaan signifikan rata-rata asupan vitamin $\mathrm{A}(\mathrm{p}=0,006)$, seng $(\mathrm{p}=0,005)$ dan zat besi $(\mathrm{p}=0,024)$ antara kelompok balita stunting dan non stunting.

Usia balita sudah mampu memilih makanan sendiri, pendidikan gizi ibu yang kurang dapat memperburuk pemilihan makanan yang memiliki nilai zat gizi yang rendah sehingga meningkatkan risiko kekurangan zat gizi pada balita (Sunarti dan Nugrohowati, 2014).

\section{Tingkat Kecukupan Vitamin A, Seng dan Zat Besi}

Pemenuhan zat gizi mikro seperti vitamin dan mineral juga penting walaupun jumlah yang dibutuhkan tidak banyak. Kurangnya tingkat kecukupan zat gizi mikro dapat terjadi karena rendahnya asupan bahan makanan sumber zat gizi mikro dalam konsumsi balita sehari-hari dan karena bioavailabilitas yang rendah (Mikhail et al., 2013). Perbedaan tingkat kecukupan vitamin A, seng dan zat besi pada balita stunting dan non stunting dapat dilihat pada Tabel 3.

\section{Tingkat Kecukupan Vitamin A}

Vitamin A memiliki peran dalam fungsi faal tubuh seperti penglihatan, diferensiasi sel, kekenalan, pertumbuhan dan perkembangan, reproduksi, pencegahan kanker dan penyakit jantung, serta berkurangnya nasfu makan (Almatsier, 2009).

Tabel 3. Perbedaan Tingkat Kecukupan Vitamin A, Seng dan Zat besi pada Balita Stunting dan non Stunting

\begin{tabular}{|c|c|c|c|c|c|c|c|}
\hline \multirow[t]{2}{*}{ Asupan } & \multicolumn{2}{|c|}{$\begin{array}{c}\text { Stunting } \\
(\mathrm{n}=19)\end{array}$} & \multicolumn{2}{|c|}{$\begin{array}{c}\text { Non Stunting } \\
(\mathrm{n}=19)\end{array}$} & \multicolumn{2}{|c|}{$\begin{array}{c}\text { Total } \\
(\mathrm{N}=39)\end{array}$} & \multirow[t]{2}{*}{ p-value } \\
\hline & $\mathbf{n}$ & $\%$ & $\mathrm{n}$ & $\%$ & $\mathbf{N}$ & $\%$ & \\
\hline \multicolumn{8}{|l|}{ Vitamin A } \\
\hline Baik & 3 & 20,0 & 12 & 80,0 & 15 & 100,0 & 0,002 \\
\hline Sedang & 5 & 60,0 & 4 & 40,0 & 9 & 100,0 & \\
\hline Kurang & 2 & 50,0 & 2 & 50,0 & 4 & 100,0 & \\
\hline Defisit & 8 & 88,9 & 1 & 11,1 & 9 & 100,0 & \\
\hline \multicolumn{8}{|l|}{ Seng } \\
\hline Baik & 5 & 29,4 & 12 & 70,6 & 17 & 100,0 & 0,003 \\
\hline Sedang & 2 & 40,0 & 3 & 60,0 & 5 & 100,0 & \\
\hline Kurang & 1 & 25,0 & 3 & 75,0 & 4 & 100,0 & \\
\hline Defisit & 11 & 91,7 & 1 & 8,3 & 12 & 100,0 & \\
\hline \multicolumn{8}{|l|}{ Zat Besi } \\
\hline Baik & 3 & 42,9 & 4 & 57,1 & 7 & 100,0 & 0,030 \\
\hline Sedang & 1 & 11,1 & 8 & 88,9 & 9 & 100,0 & \\
\hline Kurang & 0 & 0,0 & 0 & 0,0 & 0 & 100,0 & \\
\hline Defisit & 15 & 68,2 & 7 & 31,8 & 22 & 100,0 & \\
\hline
\end{tabular}


Tabel 3 menunjukkan bahwa $88,9 \%$ balita stunting mengalami defisit tingkat kecukupan vitamin A. Uji statistik Mann Whitney menunjukkan bahwa ada perbedaan tingkat kecukupan vitamin A yang signifikan antara balita stunting dan non stunting. Penelitian lain di Karangasem Bali juga menemukan perbedaan yang signifikan tingkat kecukupan vitamin A antara balita stunting dan non stunting (Suiraoka, 2011).

Asupan makanan sayur dan buah kaya akan vitamin. Sayur yang berwarna jingga lebih banyak mengandung vitamin A (Almatsier, 2009). Akan tetapi, balita stunting tidak mengonsumsi buah dan hanya suka dengan kuah sayur. Lauk pauk yang dikonsumsi oleh balita stunting yang merupakan sumber vitamin A adalah telur, tongkol dan pindang. Suplementasi vitamin A dosis tinggi masih menjadi program wajib kementerian kesehatan, namun peningkatan asupan vitamin A lebih dibutuhkan dari sumber makanan yang seimbang dan beragam.

\section{Tingkat Kecukupan Seng}

Seng selain memiliki peran penting sebagai kofaktor lebih dari 300 enzim, juga berperan dalam imunitas seluler. Peran seng ada di dalam fungsi sel $\mathrm{T}$, pembentukan antibodi oleh sel $\mathrm{B}$ dan pertahanan non spesifik (Almatsier, 2009).

Tabel 3 menunjukkan bahwa $91,7 \%$ balita stunting tingkat kecukupan seng adalah defisit atau kurang dari $70 \%$ AKG. Uji statistik Mann Whitney menunjukkan adanya perbedaan yang signifikan tingkat kecukupan seng antara balita stunting dan non stunting. Hasil penelitian ini sejalan dengan penelitian Damayanti et al. (2016) di Kelurahan Kejawan Putih Tambak Surabaya dan Anindita(2012) di Kota Semarang.

Balita dengan tingkat kecukupan seng yang tidak adekuat berisiko 7,8 kali lebih besar mengalami stunting (Damayanti et al., 2016). Kekurangan asupan seng dapat menyebabkan risiko terhadap kejadian stunting 2,67 kali lebih besar (Hidayati et al., 2010). Defisiensi seng mengakibatkan kerja hormon pertumbuhan menjadi terhambat (Aridiyah et al., 2015). Balita yang mendapat suplementasi seng memiliki pertumbuhan yang lebih baik karena konsumsi seng menstimulasi nafsu makan (Arsenault et al., 2008).

\section{Tingkat Kecukupan Zat Besi}

Balita memerlukan zat besi untuk pertumbuhan karena sebagian besar transferin darah membawa zat besi ke sumsum tulang danbagian tubuh yang lain (Almatsier, 2009). Tabel 3. menunjukkan bahwa $68,2 \%$ balita stunting tingkat kecukupan zat besi adalah defisit atau kurang dari 70\% AKG.

Uji statistik juga menunjukkan ada perbedaan yang signifikan tingkat kecukupan zat besi antara balita stunting dan non stunting. Hasil penelitian juga menunjukkan bahwa terdapat perbedaan yang signifikan tingkat asupan zat besi pada balita stunting dan non stunting (Damayanti et al., 2016). Penelitian Hidayati et al. (2010) di Surakarta menunjukkan bahwa asupan zat besi yang tidak adekuat meningkatkan risiko stunting 3,46 kali lebih besar pada balita.

Pemenuhan vitamin A, seng dan zat besi sebagian besar tidak dapat disintesa oleh tubuh sehingga dapat ditingkatkan dengan makan yang beragam dan seimbang terutama buah, sayur dan lauk hewani. Vitamin A banyak pada buah dan sayur, zat besi dari sumber makan hewani lebih mudah diserap tubuh dan seng paling banyak pada lauk hewani (Almatsier, 2009).

\section{Frekuensi Diare dan ISPA}

Infeksi dapat menjadi salah satu faktor terjadinya stunting. Penyakit infeksi yang paling banyak diderita oleh balita adalah diare dan ISPA (Lestari, et al., 2014). Balita yang sering mengalami sakit berpengaruh terhadap pertumbuhannya sebab sakit akan diikuti dengan menurunnya nafsu makan (Malde et al., 2010). Distribusi perbedaan frekuensi diare dan ISPA pada balita stunting dan non stunting dapat dilihat pada tabel 4 . 
Tabel 4. Perbedaan Frekuensi Diare dan ISPA pada Balita Stunting dan non Stunting

\begin{tabular}{|c|c|c|c|c|c|c|c|}
\hline \multirow[t]{2}{*}{ Asupan } & \multicolumn{2}{|c|}{$\begin{array}{c}\text { Stunting } \\
(\mathrm{n}=19)\end{array}$} & \multicolumn{2}{|c|}{$\begin{array}{c}\text { Non Stunting } \\
\quad(n=19)\end{array}$} & \multicolumn{2}{|c|}{$\begin{array}{c}\text { Total } \\
(\mathrm{N}=39)\end{array}$} & \multirow[t]{2}{*}{ p-value } \\
\hline & n & $\%$ & $\mathrm{n}$ & $\%$ & $\mathbf{N}$ & $\%$ & \\
\hline \multicolumn{8}{|l|}{ Sakit Diare } \\
\hline Sering & 0 & 0,0 & 0 & 0,0 & 0 & 100,0 & 0,169 \\
\hline Kadang & 2 & 50,0 & 2 & 50,0 & 4 & 100,0 & \\
\hline Jarang & 10 & 66,7 & 5 & 33,3 & 15 & 100,0 & \\
\hline Tidak Pernah & 7 & 36,8 & 12 & 63,2 & 19 & 100,0 & \\
\hline \multicolumn{8}{|l|}{ Sakit ISPA } \\
\hline Sering & 1 & 25,0 & 3 & 75,0 & 4 & 100,0 & 0,265 \\
\hline Kadang & 7 & 100,0 & 0 & 0,0 & 7 & 100,0 & \\
\hline Jarang & 8 & 40,0 & 12 & 60,0 & 20 & 100,0 & \\
\hline Tidak Pernah & 3 & 42,9 & 4 & 57,1 & 7 & 100,0 & \\
\hline
\end{tabular}

Hasil penelitian pada Tabel menunjukkan bahwa frekuensi diare maupun ISPA antara balita stunting maupun non stunting tidak menunjukkan perbedaan yang signifikan. Sebanyak $66,7 \%$ balita stunting jarang menderita diare. Frekuensi ISPA pada balita stunting hanya terjadi 3-5 kali dalam 3 bulan terakhir.

Penelitian ini sejalan dengan hasil penelitian Nasikhah dan Margawati (2012) menunjukkan bahwa riwayat penyakit infeksi tidak menjadi faktor risiko stunting.

Penelitian ini berbeda dengan di Nepal yang menunjukkan bahwa balita yang memiliki riwayat diare berisiko 7,46 kali lebih tinggi terjadi stunting (Paudel et al., 2012). Penelitian Hairunis et al. (2010) menunjukkan bahwa penyakit infeksi memiliki pengaruh yang signifikan terhadap stunting pada anak balita di wilayah kerja Puskesmas Soromandi Kabupaten Bima NTB. Perbedaan ini terjadi karena data mengenai sakit infeksi dalam penelitian ini didapatkan dengan metode wawancara langsung dengan mengingat kejadian selama tiga bulan yang lalu sebelum penelitian.

Infeksi akan merespons peningkatan sitokin TNF- $\alpha$ dan IL-1 ketika akan terjadi peradangan sebagai salah satu sistem pertahanan tubuh terhadap benda asing. Sitokin TNF- $\alpha$ dan IL-1 yang meningkat akan menurunkan hormon IGF-1 yang merupakan hormon pertumbuhan. IGF-1 yang menurun akan memengaruhi pertumbuhan lempeng epifisis tulang panjang sehingga pertubuhan linier anak tidak maksimal (Adriani dan Wirjatmadi, 2012).

Keterbatasan penelitian ini metode recall yang digunakan dalam penelitian memiliki bias ingatan dan menentukan ukuran rumah tangga (URT). Peneliti menggunakan food model untuk mengurangi bias tersebut.

\section{KESIMPULAN DAN SARAN}

Kesimpulan dari penelitian ini asupan dan tingkat kecukupan vitamin A, seng dan zat besi pada balita stunting lebih rendah dibandingkan balita non stunting. Frekuensi diare dan ISPA pada balita stunting dan non stunting tidak menunjukkan perbedaan yang signifikan. Perlu peningkatan yang adekuat dengan asupan vitamin $\mathrm{A}$, seng dan zat besi mengonsumsi makanan yang beragam dan seimbang untuk mencegah terjadinya stunting pada balita.

\section{DAFTAR PUSTAKA}

Adriani, M., \& Wirjatmadi, B. (2012). Gizi dan kesehatan balita. Jakarta:Kencana Prenada Media Group.

Almatsier. (2009). Prinsip dasar ilmu gizi. Jakarta: PT. Gramedia Pustaka Utama.

Anindita, P. (2012). Hubungan tingkat pendidikan ibu, pendapatan keluarga, kecukupan protein \& zinc dengan stunting (pendek) pada balita usia 6-35 bulan di Kecamatan tembalang Kota Semarang. Jurnal Kesehatan Masyarakat, 1(2) 
Diakses dari http://ejournals1.undip.ac.id/ index.php/jkm.

Aridiyah, F.O., Rohmawati, N., \& Ririanty, M. (2015). Faktor-faktor yang memengaruhi kejadian stunting pada anak balita di wilayah pedesaan dan perkotaan. E-Jurnal Pustaka Kesehatan, 3,1. Diakses dari jurnal.unej.ac.id/ index. php/JPK/article/download/2520/2029.

Arsenault, J.E., Roman, D.L., Penny, M., Loan, M.D., \& Brown, K.H. (2008). Additional zinc delivered in a liquid supplement, but not in a fortified porridge, increased fat-free mass accrual among young peruvian children with mild-to-moderate stunting. J. Nutr, 138, 108114. Diakses dari www.ncbi.nlm. nih.gov/ pubmed/18156412.

Chaerunnimah., Wirjatmadi, B., \& Adriani, M. (2011). Perbedaan kejadian infeksi setelah pemberian seng pada balita gizi baik usia 3-5 tahun di Kabupaten Bojonegoro. Media Gizi Pangan, 12(2) Diakses dari https://jurnalmedia gizipangan.files.wordpress.com/2012/03/ media-gizi-pangan-volume-xii-edisi-2-juli_ desember-2011.pdf.

Damayanti, R. A., Muniroh, L., \& Farapti. (2016). Perbedaan tingkat kecukupan zat gizi dan riwayat pemberian ASI eksklusif pada balita stunting dan non stunting. Media Gizi Indonesia, 11(1) Diakses dari https://e-journal.unair. ac.id/ MGI/article/view/4393\&ved=2ahUKEwily9 Dh74DZAhVLNY8KHcw3BmoQFjAAegQI ERAB\&usg=AOvVaw0V2usCE7VbGKXwu Y6jPEFJ.

Dinas Kesehatan Kota Surabaya. (2016). Prevalensi balita stunting dalam tiga tahun terakhir di Kota Surabaya. Surabaya: Departemen Kesehatan Kota Surabaya.

Hardiansyah, D.E., \& Zulianti, W. (2008). Hubungan konsumsi susu dan kalsium dengan desitas tulang dan tinggi badan remaja. Jurnal Gizi dan Pangan, 3(1):43-48. Diakses dari http://download.portal garuda.org/article. php\%3Faritcle\%3D5331.

Hidayati, L., Hadi, H., \& Kumara, A. (2010). Kekurangan nergi dan zat gizi merupakan faktor risiko kejadian stunted pada anak usia 1-3 tahun yang tinggal di wilayah kumuh perkotaan Surakarta. Jurnal Kesehatan. 3: 89-104. Diakses dari https://publikasiilmiah. ums.ac.id/bitstream/handle/11617/2315/10.\%20 LISTYANI\%20H.pdf?sequence $=1$.
Hoddinott, J., J.R. Behrman, J.A. Maluccio, P. Melgan, A.R. Quisumbing, M. Ram irezzea, dkk. (2013). Adult consequences of growth failure in early childhood. The American Journal of Clinical Nutrition, 98(5): 1170-1178. Diakses dari http://ajen. nutrition.org/cont ent $/ 98 / 5 / 1170$.full.

Khan, A.I., I. Kabir., E.C. Ekstrom., K.A. Monemi., D.S. Alam., E.A. Frongillo., M. Yunus., A. Arifeen., \& L.A. Persson. (2011). Effect of prenatal food and micronutrient supplementation on child growth from birth to 54 months of age: A randomized trial in Bangladesh. Nutrition Journal, (10): 134. Diakses dari https://www. ncbi.nlm.nih.gov/pubmed/22152147.

Kuntoro. (2008). Metode sampling dan penentuan besar sampel. Surabaya: Pustaka Melati.

Lestari, W., Margawati, a., \& Rahfiludin, M. (2014). Faktor risiko stunting pada anak umur 6-24 bulan di Kecamatan Penanggalan Kota Subussalam Provinsi Aceh. Jurnal Gizi Indonesia, 3(1), 37-45. Diakses dari http:// ejournal.undip.ac.id/index. php/jgi/article/ download/8752/7081.

Malde, M.K., Zerihun, L., Bjorvatn, K., \& Julshamn, K. (2010). Intake of iron, zinc and iodine in 28 Ethiopian children living in Wonji Shoa sugar estate, assessed by duplicate portion technique. Academic Journals, 5(8), 730-736. Diakses dari http://www.academicjournals.org/SRE.

Mikhail, W.Z.A., Sobhy, H.M., El-Sayed, H.H., Khiry, S.A., Abu Salem, H.Y.H., \& Samy, M.A. (2013). Effect if nutritional status on growth pattern of stunted preschool children in Egypt. Academic Journal of Nutrition, 2(1); 1-9, doi:10.5829/ idosi.ajn.2013.2.1.7466. diakses dari http://www.idosi.org/ajn/2(1)13/1.pdf.

Nasikhah, R., \& Margawati, A. (2012). Faktor resiko kejadian stunting pada balita usia 24-36 bulan di Kecamatan Semarang Timur. Journal of Nutrition College. 1(1), 176-184. Diakses dari https:// ejournal3.undip.ac.id/index.php/jnc/ article/view/738\&ved=2ahUKEwi8h96o8YDZ AhWHLI8KHfCyAj8QFjAAegQIExAB.

Paudel R., Pradhan B., Wagle RR., Pahari DP., \& Onta SR.(2012). Risk factors for stunting among children: A community based case control study in Nepal. Kathmandu University Medical Journal. Vol. 10 No. 3:18-24. Diakses dari https:// www.ncbi.Nlm.nih.gov/ pubmed/23434956. 
Picauly, I., \& Toy, M.S. (2013). Analisis determinan dan pengaruh stunting terhadap prestasi belajar anak sekolah di Kupang dan Sumba Timur NTT. Jurnal Gizi dan Pangan, 8(1): 55-62. Diakses dari http://journal.ipb.ac.id/ondex.php/ jgizipangan/article/view/7254/5665.

Roscha, B.C., Putri, B.S.K., \& Putri, I.Y.S. (2013). Determinan status gizi pendek anak balita dengan riwayat berat badan lahir rendah (BBLR) di Indonesia (Analisis Data Riskesdas 2007-2010). Jurnal Ekologi Kesehatan, 12(3), 195-205. Diakses dari http://ejournal. litbang. depkes.go.id/index.php/jek/article/ download/3866/3716.

Suiraoka, I Putu., Kusumajaya, AAN., \& Larasari, Nuki. (2011). Perbedaan konsumsi energi, protein, vitamin a dan frekuensi sakit karena infeksi pada anak balita status gizi pendek (stunted) dan normal di Wilayah Kerja Puskesmas Karangasem I. Jurnal Ilmu Gizi. Vol. 2 No.1. Diakses dari http://poltekkesdenpasar. ac.id/files/JIG/V2N1/Suiraoka.pdf.

Sunarti., \& Nugrohowati, A.K. (2014). Korelasi status gizi, asupan zat besi dengan kadar feritin pada anak usia 2-5 tahun di Kelurahan Semanggi Surakarta. Jurnal Kesehatan Masyarakat, 8(1), 11-18. Diakses dari http://journal.uad.ac.id/ index.php/KesMas/article/download/1037/76.

Wardyaningrum, D. (2011). Tingkat kognisi tentang konsumsi susu pada ibu peternak sapi perah lembang Jawa Barat. Jurnal Al-AZHAR INDONESIA SERI PRANATA SOSIAL, 1(1) index.php /SPS/article/download/6/4. 